\title{
Studies on Solid Electrolytes for a New-type SOFC using Methane-Air Mixture
}

\author{
Koichi ASANO, Takashi HIBINO and Hiroyasu IWAHARA*
}

Received December 21, 1995 ; Accepted March 14, 1996

\begin{abstract}
In order to find out a suitable electrolyte for a new-type SOFC (one chamber with methane - air mixture), YSZ ( 8 mol\% $\mathrm{Y}_{2} \mathrm{O}_{3}$ ) doped with $\mathrm{TiO}_{2}$ was tested as a solid electrolyte. In the case of nondoped YSZ, the open - circuit voltage of the cell decreased with time, and the electric power density was extremely smaller than the value obtained in a conventional SOFC using YSZ as a solid electrolyte. However, in the case of $\mathrm{YSZ}$ doped with $\mathrm{TiO}_{2}(5 \mathrm{~mol} \%)$, the electric power density was about 6 times higher than that in the case of YSZ only, although the terminal voltage of the cell-slightly decreased with time. This was based on the difference in cathodic polarization and transitional change in the potential between these electrolytes.
\end{abstract}

\section{INTRODUCTION}

High temperature solid oxide fuel cells (SOFCs) are expected as effective and clean energy conversion system, and many studies have been done on its electrolyte, electrode and power generation systems. However, since fuel and oxidant gases must be supplied separately in the conventional SOFC, a high temperature gas sealing is needed. Thus, this requires the intricate and expensive apparatus.

As reported earlier by van Gool' ${ }^{1)}$ and Louis et al. ${ }^{2)}$, a fuel cell which works in the mixture of fuel and oxidant (air) can be constructed if it has an electrode active against only fuel and an electrode inactive against the fuel but active for ionization of oxygen. However, this type cell is impossible for normal complete combustion system.

We have reported a new-type SOFC $^{3-5}$ ) which works in a uniform atmosphere (the mixture of $\mathrm{CH}_{4}$ and air) and produces electric power as well as synthetic gas $\left(\mathrm{CO}+2 \mathrm{H}_{2}\right)$ for a methanol synthesis. This type SOFC can be a system for chemical cogeneration of both electric power and useful chemicals. The working mechanism of this type cell was found to be based on the difference in catalytic

Center for Integrated Research in Science and Engineering, Nagoya University (Furo-cho, Chikusa-ku, Nagoya 464-01, Japaul)

Key Words : new-type SOFC, methane-air mixture, mixed conductor, poralization activity between $\mathrm{Pt}$ and $\mathrm{Au}$ for the partial oxidation of $\mathrm{CH}_{4}$ to form $\mathrm{H}_{2}$ and $\mathrm{CO}$ (synthetic gas) given by Eq.(1).

$$
\mathrm{CH}_{4}+1 / 2 \mathrm{O}_{2} \rightarrow \mathrm{CO}+2 \mathrm{H}_{2}
$$

If an electrode material, which can oxidize $\mathrm{CH}_{4}$ partially, is attached to one side of the solid electrolyte and an electrode material inert for this reaction on another side, as shown in Fig. 1(a), $\mathrm{CH}_{4}$ is oxidized to $\mathrm{H}_{2}$ and $\mathrm{CO}$ on the former, but it does not react on the latter. This leads to an oxygen concentration cell between two electrodes, so that a large EMF can be obtained, even using, a A-type cell in the gaseous flow of $\mathrm{CH}_{4}$-air. This SOFC system requires only simple and inexpensive equipment, since no gas separation is needed between fuel gas and air. When using $\mathrm{BaCe}_{0.8} \mathrm{Y}_{0.2} \mathrm{O}_{3-\alpha}$ as a solid electrolyte, this type cell generated a maximum electric power density of about $0.17 \mathrm{Wcm}^{-2}$ with the current density of $400 \mathrm{mAcm}^{-2}$ and the terminal voltage of $420 \mathrm{mV}$ ). However, the life of this cell was rather short because $\mathrm{BaCeO}_{3}$-based ceramic electrolyte gradually reacts with $\mathrm{CO}_{2}$ to form $\mathrm{BaCO}_{3}$ on the surface of the electrolyte and the terminal voltage as well as the power density decreased with time ${ }^{6)}$. On the other hand, yttria-stabilized zirconia $\left(\left(\mathrm{ZrO}_{2}\right)_{0.92}\left(\mathrm{Y}_{2} \mathrm{O}_{3}\right)_{0.08} ; \mathrm{YSZ}\right)$ as a solid electrolyte, which is used in a currently developing SOFC, is very stable against $\mathrm{CO}_{2}$. However, when it was used for this new- 


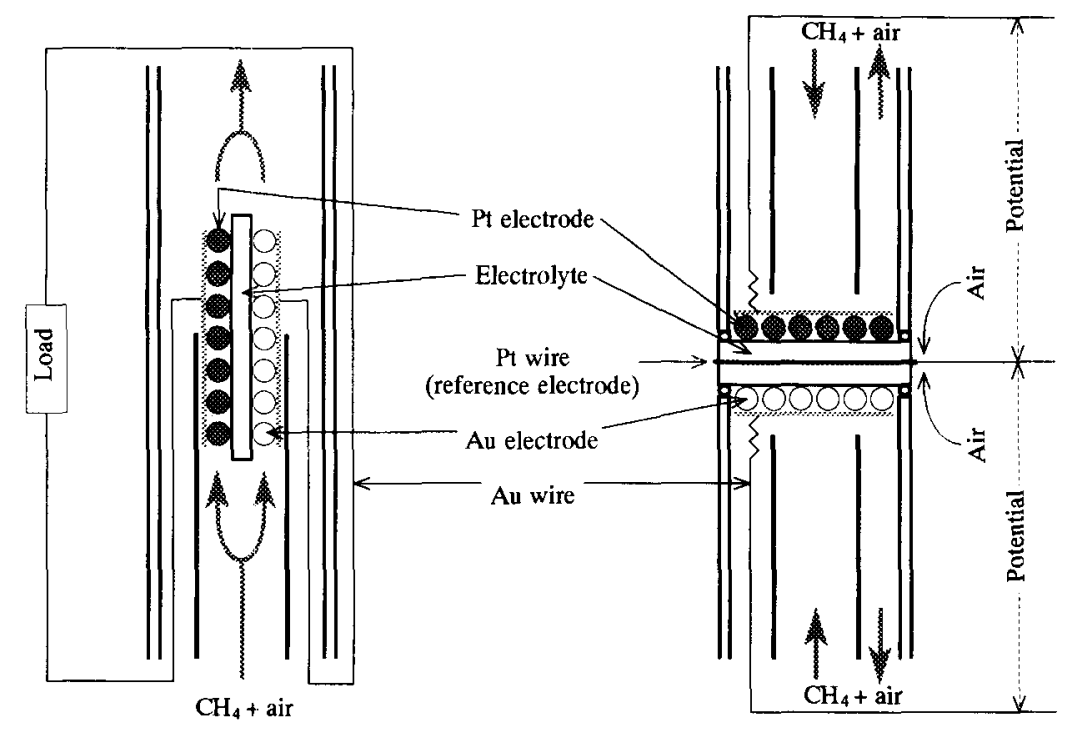

(a) A-type cell

(b) B-type cell

Fig. 1 Schematic illustrations of test cells ((a) A-type cell and (b) B-type cell).

type cell, the power density was very much lower than that of the SOFC using $\mathrm{BaCeO}_{3}$ as a solid electrolyte because of its large cathodic overpotential of $\mathrm{Au}$ electrode ${ }^{4)}$. Hence, in order to gain the satisfactory power density, it is necessary to reduce the cathodic overpotential. In general, Au metal is inactive to the adsorption, diffusion or ionization of oxygen molecule or atom. However, if a solid electrolyte slightly contains the electronic conduction, the polarization characteristic of Au electrode may be improved due to an increase in the so-called three-phase reaction area (electrolyte/electrode/gas) ${ }^{\text {7) }}$ or due to catalytic activity of such electrolyte surface. This may be the reason why the cell with $\mathrm{BaCeO}_{3}$ based electrolyte which has p-type electronic conduction exhibits good characteristics.

In this study, an attempt was made to improve the performance of a new-type SOFC using YSZ as a solid electrolyte in which $\mathrm{TiO}_{2}^{8-10)}, \mathrm{CeO}_{2}, \mathrm{~Tb}_{4} \mathrm{O}_{7}$ or $\operatorname{Pr}_{6} \mathrm{O}_{11}$ was intentionally contained. It is well known that the conduction in $\mathrm{TiO}_{2}$ - and $\mathrm{CeO}_{2}$-doped $\mathrm{ZrO}_{2}$ shows partially n-type electronic under reducing atmosphere and $\mathrm{Tb}_{4} \mathrm{O}_{7}$ - and $\mathrm{Pr}_{6} \mathrm{O}_{11}$-doped $\mathrm{ZrO}_{2}$ shows partially $\mathrm{p}$ type electronic conduction under oxidizing atmosphere. The electrochemical cells were constructed and their characteristics were examined to study the properties of the materials as a solid electrolyte for this cell.

\section{EXPERIMENTAL}

\subsection{Preparation of YSZ doped with $\mathrm{TiO}_{2}$} ceramic

$\mathrm{TiO}_{2}$-doped YSZ ceramics $(\mathrm{YSZ})_{1-\mathrm{x}}\left(\mathrm{TiO}_{2}\right)_{\mathrm{x}}(\mathrm{x}=0$, $0.03,0.05,0.1)$ were prepared by a solid state reaction of ytria stabilized zirconia, $\left(\mathrm{ZrO}_{2}\right)_{0.92}\left(\mathrm{Y}_{2} \mathrm{O}_{3}\right)_{0.08}$ (Tosoh, TZ-8Y powder) and $\mathrm{TiO}_{2}$ powders. The desired amounts of raw materials were mixed and calcined in air at $1523 \mathrm{~K}$ for $10 \mathrm{hrs}$. The oxide was ground in a ball mill and pressed hydrostatically into the pellet under the pressure of $2 \times 10^{3} \mathrm{~kg} \mathrm{~cm}^{-2}$. The pellet was finally sintered in air at $1823 \mathrm{~K}$ for $10 \mathrm{hrs.}(\mathrm{YSZ})_{0.95}\left(\mathrm{MO}_{\mathrm{y}}\right)_{0.05}$ $(\mathrm{M}=\mathrm{Tb}, \mathrm{Pr}, \mathrm{Ce})$ were prepared in the same manner as a (YSZ) $)_{1-x}\left(\mathrm{TiO}_{2}\right)_{\mathrm{x}}$. These density of sintered pellets was higher than $95 \%$ of their theoretical density, and the crystal phase was confirmed to be a single fluoritetype structure by $\mathrm{X}$-ray diffraction measurements using $\mathrm{Cu} \mathrm{K} \alpha$, but the ceramics of $\mathrm{x}=0.1$ showed second phase.

\subsection{Solid oxide fuel cell}

The structure of the test cell is shown in Fig. 1(a) (A-type cell). The specimen electrolyte ceramic was cut into a plate $(8.5 \times 8.5 \times 0.5 \mathrm{~mm})$, and commercial Pt paste was painted on one face of the plate and $\mathrm{Au}$ on the other face. To ensure the intimate contact between the porous electrode and the electrolyte, the specimen was baked at $1223 \mathrm{~K}$ for several hours. The electrode area was $0.20 \mathrm{~cm}^{2}$. Au lead wire served as output terminals for Pt and Au electrodes. The test 
gas was prepared by mixing $\mathrm{CH}_{4}$ with air to obtain the desired $\mathrm{CH}_{4}: \mathrm{O}_{2}=2: 1$ ratio. The flow rate was $210 \mathrm{ml} \mathrm{min}^{-1}$. The operating temperature was $1223 \mathrm{~K}$.

In order to measure the potential and polarization characteristic of each electrode, an alternative test cell was constructed as shown in Fig. 1(b) (B-type cell). The specimen disk (diameter $12 \mathrm{~mm}$, thickness 0.5 $\mathrm{mm}$ ) was used as a solid electrolyte. Pt and Au pastes were baked at $1223 \mathrm{~K}$ in the same manner as the A-type cell. The electrode area was $0.5 \mathrm{~cm}^{2}$. The structure of this cell was similar to that of a conventional fuel cell. However, in contrast to the conventional cell, the $\mathrm{CH}_{4}$ + air mixture with the same composition $\left(\mathrm{CH}_{4}: \mathrm{O}_{2}=2\right.$ : 1) was supplied to both electrode compartments. A reference electrode was attached to the circumference of the electrolyte disk by winding a Pt wire with a Pt paste and baking it. Therefore, the reference electrode is exposed to air whose $\mathrm{Po}_{2}$ is constant. The overpotential of each electrode was measured by the current interruption method with using current pulse generator (Nikko Keisoku current pulse generator NCPG-101).

\section{RESULTS AND DISCUSSION}

\subsection{Cell characteristics}

Fig.2(a) shows the terminal voltage of an A-type cell using YSZ as a solid electrolyte at $1223 \mathrm{~K}$. When a methane+air mixture was introduced into the A-type cell, the open-circuit voltage built up rapidly and then decreased gradually down to about $230 \mathrm{mV}$. On the other hand, in the cell using $(\mathrm{YSZ})_{0.95}\left(\mathrm{TiO}_{2}\right)_{0.05}$ as a solid electrolyte, the steady state open-circuit voltage was about $470 \mathrm{mV}$, although the initial voltage slightly decreased with time after small overshoot shown in Fig.2(b).

Current could be stably drawn from both cells as shown in Fig.2 (a) and (b). However, in the case of YSZ, the value was extremely small. On the other hand, in the case of YSZ doped with $\mathrm{TiO}_{2}(5 \mathrm{~mol} \%)$, the value was higher than that in the case of YSZ only.

Figure 3 shows the relation between the terminal voltage and discharge current density of the A-type cell using (YSZ) $)_{1-x}\left(\mathrm{TiO}_{2}\right)_{x}$ at $1223 \mathrm{~K}$. A steady and stable current could be drawn from the cells. Plots of the terminal voltage against the current density somewhat deviated form linear relation suggested the existence of electrode polarization. The maximum electric power density of (YSZ) $)_{1-\mathrm{x}}\left(\mathrm{TiO}_{2}\right)_{\mathrm{x}}$ at $1223 \mathrm{~K}$ are shown in Fig. 4. Among these oxides examined, the best perfor-
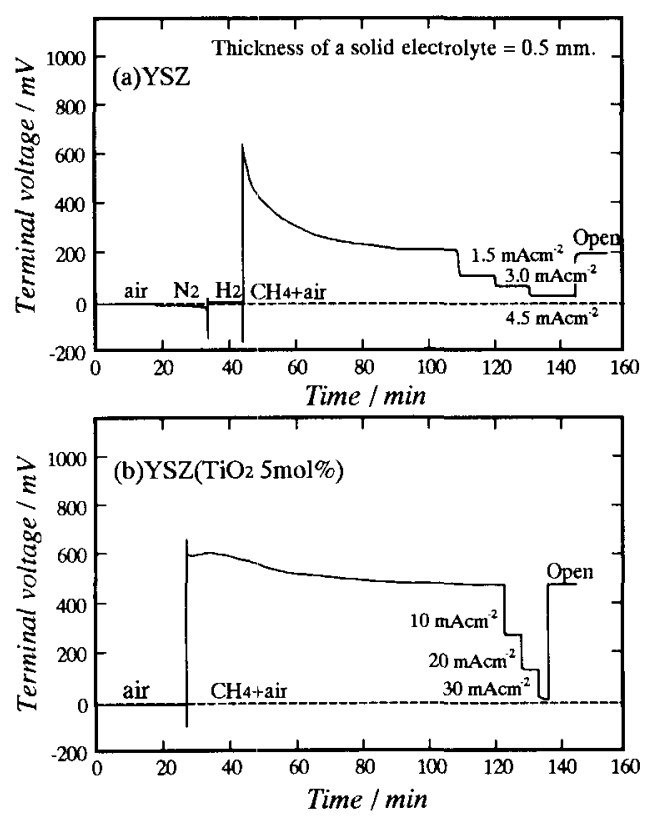

Fig.2 Transitional change in the terminal voltage of the A-type cell with time at $1223 \mathrm{~K}$. Electrolyte; (a)YSZ, (b) $(\mathrm{YSZ})_{0.95}\left(\mathrm{TiO}_{2}\right)_{0.05}$.

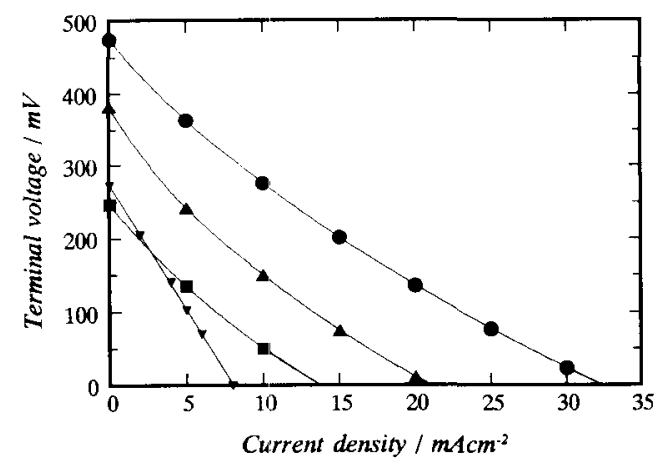

Fig.3 Typical discharge characteristics of the A-type cell at $1223 \mathrm{~K}$. $\mathrm{X}$ in $(\mathrm{YSZ})_{1-\mathrm{x}}\left(\mathrm{TiO}_{2}\right)_{\mathrm{x}} ; \boldsymbol{\nabla}: \mathrm{x}=0$, $: \mathrm{x}=0.03$, : $\mathrm{x}=0.05, \mathrm{a}: \mathrm{x}=0.1$.

mance was obtained in $\mathrm{x}=0.05$ cell with about $3.0 \mathrm{~mW}$ $\mathrm{cm}^{-2}$ (a current density of $16 \mathrm{~mA} \mathrm{~cm} \mathrm{~cm}^{-2}$ and a terminal voltage of $190 \mathrm{mV}$ ). However, these values are still far low compared with the value of about $170 \mathrm{~mW} \mathrm{~cm}^{-2}$ observed in the celll using $\mathrm{BaCe}_{0.8} \mathrm{Y}_{0.2} \mathrm{O}_{3-\alpha}$ as a solid electrolyte.

The cells of this kind were also constructed using $\mathrm{Tb}$ or $\mathrm{Pr}$ as a solid electrolyte. Figure 5 shows the typical example of the cell performance. Although $\mathrm{Tb}_{4} \mathrm{O}_{7}$-doped electrolyte cell shows somewhat the 


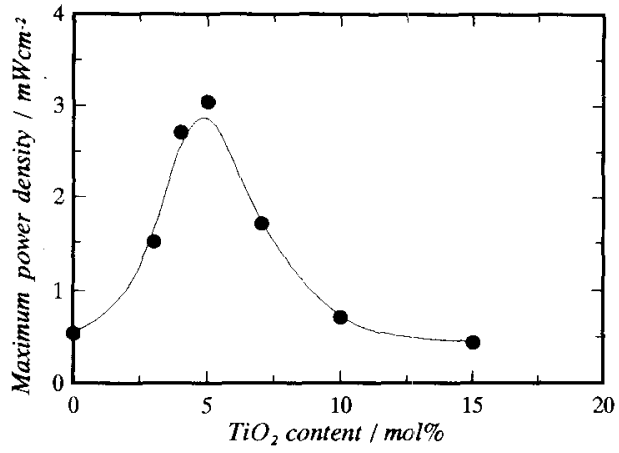

Fig.4 Maximum power density of the A-type cell at $1223 \mathrm{~K}$.

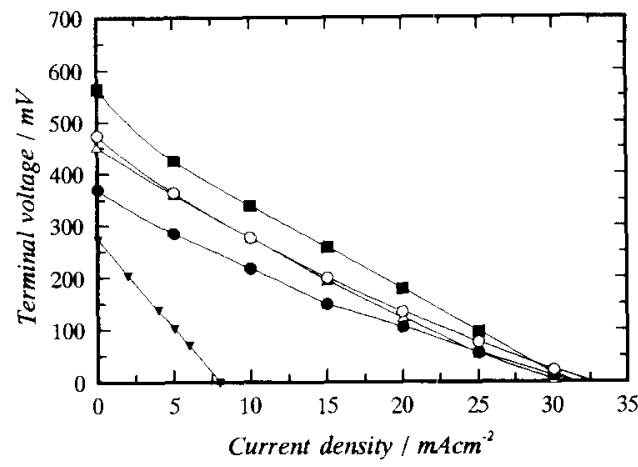

Fig.5 Typical discharge characteristics of the A-type cell at $1223 \mathrm{~K}$. YSZ $(\boldsymbol{\nabla}),(\mathrm{YSZ})_{0.95}\left(\mathrm{MO}_{\mathrm{x}}\right)_{0.05} ; \mathrm{M}=\mathrm{O}$ $: \mathrm{Ti}, \mathbf{\square}: \mathrm{Tb}, \triangle \mathrm{Ce}, \mathrm{O}: \mathrm{Pr}$.

higher performance than $\mathrm{TiO}_{2}$-doped one, the reproductivity of the cell performance was not as good as that of $\mathrm{TiO}_{2}$-doped YSZ cell.

\subsection{Transitional change in the potential}

In order to understand the difference in the discharge characteristics between $\mathrm{TiO}_{2}$-doped $\mathrm{YSZ}$ and undoped YSZ cells, the transitional change in potentials with time was measured using a B-type cell, in which the reference electrode was attached to the circumference of the electrolyte disk. Figure $6(\mathrm{a})$ and (b) show the results for the cell using (YSZ) $)_{1-x}\left(\mathrm{TiO}_{2}\right)_{x}$ $(x=0,0.05)$ as a solid electrolyte. The initial potential of $\mathrm{Au}$ electrode on $\mathrm{YSZ}(\mathrm{x}=0)$ was nearly the same as the value of the reference electrode which was exposed to atmospheric air. Then, the potential gradually shifted to the negative direction with time. On the other hand, the potential of Pt electrode was far negative, and was nearly constant with time. This result suggests that $\mathrm{Au}$ electrode came to exhibit the catalytic activity for the partial oxidation of methane
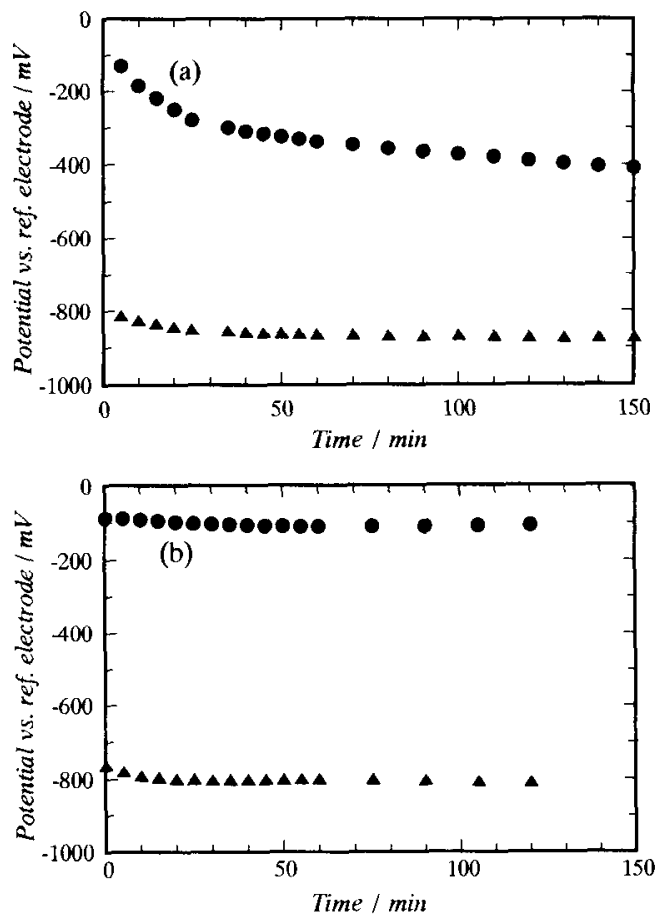

Fig.6 Transitional change in potentials of $\mathrm{Pt}(\boldsymbol{\Delta})$ and $\mathrm{Au}(\mathrm{O})$ electrodes with time in the B-type cell at 1223K. Electrolyte; (a)YSZ, (b) $(\mathrm{YSZ})_{0.95}\left(\mathrm{TiO}_{2}\right)_{0.05}$.

with time. In short, this means that $\mathrm{Au}$ electrode became to be inferior to the function as cathode. On the other hand, in the case of $x=0.05$, the potential of Au electrode moved only slightly to negative direction. The open-circuit potential of $\mathrm{Pt}$ electrode was slightly somewhat higher than that of undoped YSZ cell. The open-circuit potential at the initial stage is rather less negative compared to the cell with undoped YSZ. This suggests that the electronic conduction in $(\mathrm{YSZ})_{0.95}\left(\mathrm{TiO}_{2}\right)_{0.05}$ electrolyte contributed to the potential of Pt electrode.

\subsection{Polarization characteristic}

The cathodic and anodic overpotential characteristics (frec from ohmic loss) of B-type cell were shown in Figure 7 (a) and (b). In the case of YSZ $(x=0)$, the overpotential of Au electrode was much larger than that of Pt electrode. This indicates that the voltage drop observed in the A-type cell is mainly ascribed to the polarization of $\mathrm{Au}$ electrode. In general, Au metal is inactive to the adsorption and/or ionization of oxygen gas. If these behaviors cause a large cathodic overpotential, the polarization characteristics of Au electrode may be improved by 

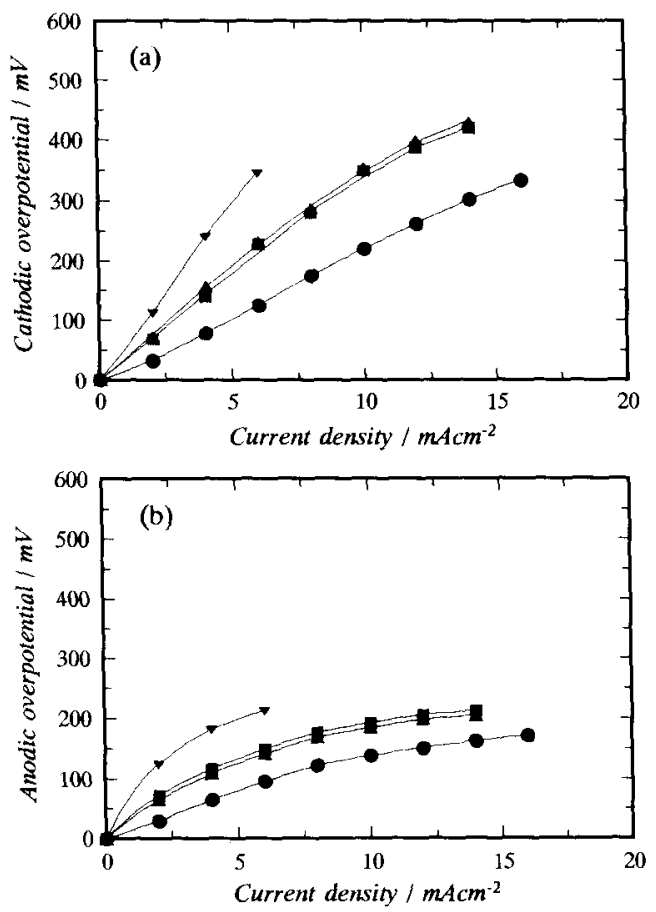

Fig.7 Polarization characteristics of $\mathrm{Au}(\mathrm{a})$ and $\mathrm{Pt}(\mathrm{b})$ electrodes in the B-type cell at $1223 \mathrm{~K} . \mathrm{X}$ in $(\mathrm{YSZ})_{1-\mathrm{x}}$ $\left(\mathrm{TiO}_{2}\right)_{\mathrm{x}} ; \nabla: \mathrm{x}=0, \Delta: \mathrm{x}=0.03, \mathrm{O}: \mathrm{x}=0.05, \mathbf{\square}: \mathrm{x}=0.1$.

using partial electronic conductor as described with the introduction section and in the related papers concerning $\mathrm{BaCeO}_{3}$ or $\mathrm{SrCeO}_{3}$-based electrolytes ${ }^{4}$ ). In fact, the cathodic overpotential decreased with increasing content of $\mathrm{Ti}$ up to $\mathrm{x}=0.05$. However, in the case of $x=0.1$, the overpotential was large probably due to be the existence of the second phase.

Thus, as a solid electrolyte for the new-type SOFC, $(\mathrm{YSZ})_{1-\mathrm{x}}\left(\mathrm{TiO}_{2}\right)_{\mathrm{x}}$ ceramic in which electronic conduction is intentionally contained, are better than YSZ itself in its OCV and polarization characteristics. However, the cause of the effect of electronic conduction on potential and polarization is not clear now although it will be ascribed to some phenomena around the boundary between electrolyte and electrode. Accordingly, one of the promising materials for this type of the new-type cell will be a surface modified yttria-stabilized zirconia with electronic conduction. We will report on the SOFC system using the material as a solid electrolyte in a future paper.

\section{CONCLUSION}

The electric power density of a new-type SOFC using methane+air mixture could be improved by adding the electronic conduction in YSZ as a solid electrolyte. Among the oxides (YSZ) $\left(\mathrm{TiO}_{2}\right)_{1-\mathrm{x}}$ examined, the best performance was obtained in $\mathrm{x}=0.05$ at $1223 \mathrm{~K}$. The potential of Au electrode on $x=0.05$ electrolyte was stable compared to that in undoped YSZ, and the overpotential decreased with increasing content of $\mathrm{Ti}$ up to $\mathrm{x}=0.05$.

This work was partially supported by the Grant-inAid for Scientific Research on Priority Areas (No.260) from The Ministry of Education, Science and Culture.

\section{FEFERENCES}

1) W. van Gool, Philips Res. Repts., 20, 81 (1965).

2) G. A. Louis, J. M. Lee, D. L. Maricle and J. C. Trocciola, U. S. Pat. No. 4248941 (1981).

3) T. Hibino and H. Iwahara, Chem. Lett, , 7, 1131 (1993).

4) T. Hibino, K. Asano and H. Iwahara, Chem. Lett., 3, 485 (1994).

5) K. Asano, T. Hibino and H. Iwahara, J. Electrochem. Soc., 142, 3241 (1995).

6) M. J. Scholten, J. Schoonman, J. C. van Miltenburg and H. A. J. Oonk, Solid State Ionics, 61, 83(1993).

7) T. Takahashi, H. Iwahara and I. Ito, Denki Kagaku, 38, 509 (1970).

8) S. S. Liou and W. L. Worrell, Appl. Phys., A49, 25 (1989)

9) N. Matsui, Denki Kagaku, 58, 716 (1990).

10) H. Naito and H. Arashi, Solid State Ionics, 5356, 436 (1992). 